\title{
ENERGY ANALYSIS OF SIMULTANEOUS SPACE COOLING AND HOT WATER SUPPLY USING HEAT PUMP ${ }^{1}$
}

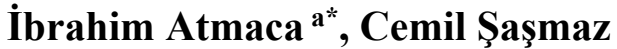 \\ $a^{*}$ Akdeniz University, Engineering Faculty, Mechanical Engineering Department, Antalya \\ atmaca@akdeniz.edu.tr
}

\begin{abstract}
Environmental awareness is increased and heat pump systems have become more common because of several reasons such as; the depletion of fossil fuels and environmental harm caused by the fossil fueled air-conditioning systems. Heat pumps can be air source, waterborne, ground source due to the ambient that they transfer or reject heat. Water is the most efficient way to transfer heat in comparison to other resources. Considering cooling systems, waterborne systems are more efficient and smaller than air source systems. As it is known, air temperature is very high in the Mediterranean region hence COP (coefficient of performance) of air source heat pumps decrease. This study carries out the energy analysis of a heat pump which transfers the heat between cooled space and hot water tank. The waterborne air pump is installed in the Thermodynamics Laboratory of Engineering Faculty of Akdeniz University and the energy analysis of both cooling system and hot water supply is performed based on various parameters for a sample day. Mean water heating, space cooling and overall COP are calculated as $2.61,2.08$ and 4.69 , respectively.
\end{abstract}

Keywords: Heat pump, hot water, space cooling, energy analysis

\section{Introduction}

Along with major industrial and technological developments, population growth and individuals' desire to live better have gradually increased the consumption and energy prices. Because of this, the efforts on energy have been concentrated on increasing the energy efficiency. Efficient use of energy has become one of the most important issues as much as its production. There are various methods available for energy recovery (especially for heat energy). Heat pumps offer efficient and economical solutions for the recovery of heat energy from heat resources which have large potential but low temperature. A heat pump is a system

${ }^{1}$ This study is supported by the Scientific Research Projects Coordination Unit of Akdeniz University (project no: 2010.01.0102.011) 
that simply conveys heat energy from one environment to another and is fed electrically. When the necessary conditions are met, high amounts of energy can be used at low cost.

Many studies are available in the literature for heat pumps that use various sources such as air, water, soil for heating or cooling purposes and for hot water supply during the operation. Jiang et al. [1] have investigated hot water production using the heat from space cooling, and found out that the performance coefficient of total energy used is $38.6 \%$ higher than the conventional systems. The refrigerant used in the heat pump is R22. Shao et al. [2] conducted analyzes on cooling and hot water supply and reported that energy consumption is decreased by $31.1 \%$ compared to conventional systems. Fatouh and Elgendy [3] analyzed the simultaneous cooling and hot water supply of a heat pump operating with R134A refrigerant, and reported that COP is in the range of $1.9-3.1$ in only cooling, $2.9-3.3$ in only heating, and concluded that a compound COP reaches up to $3.7-4.9$. There are more studies on this topic in the literature [4-7].

In this study, a water-to-water heat pump system is tested for simultaneous space cooling and hot water supply in summer. While the space is cooled by the heat from evaporator, the hot water is simultaneously obtained with the heat from condenser. Energy analysis is performed with the measurements obtained for a sample day when the seasonal conditions were normal and the weather was clear.

\section{Materials and method}

The general flow diagram of the studied water-to-water heat pump is given in Figure 1. The heat absorbed from the environment by the fan - coil devices will be transferred to the working fluid R410A in the HP4 evaporator, then the working fluid will be raised to high temperature and pressure by the compressor. In the HP2 condenser, the working fluid will transfer the heat to the water and this heat will be transferred to the tank. Thus, while cooling the space, hot water will be produced at the same time.

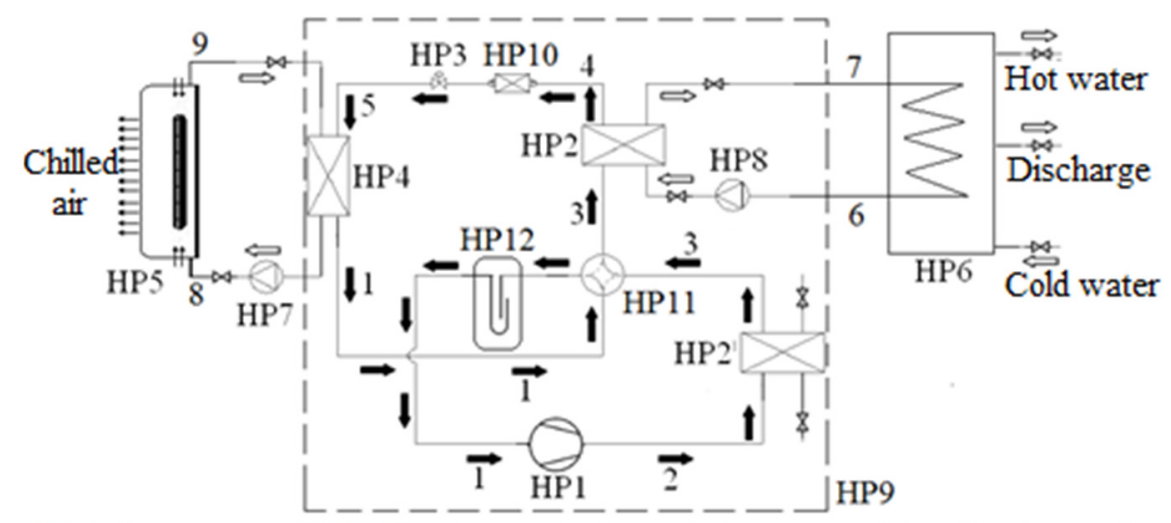

HP1-Compressor, HP2'-Condenser for domestic hot water, HP2-Condenser for airconditioner, HP3-Expansion valve, HP4-Evaporator, HP5-Fan-coil unit, HP6-Heat storage tank, HP7-Circulating pump I, HP8-Circulating pump II, HP9-Heat pump unit, , HP10-Non-return valve, HP11-Four-way valve, HP12-Gas-liquid separator

Figure 1. General flow layout

The system is operated under summer conditions to make simultaneous cooling and hot water supply. The cooled space was $110 \mathrm{~m}^{2}$ laboratory and the rejected heat is transferred to 2-ton capacity tank where the hot water is obtained. 5 hours of cooling and hot water supply is realized between 09:00 am and 2:00 pm for a sample day, and the system is stopped at 2:00 
am because the cooling performance decreased with increasing tank water temperature. During the operation period, the measurement and screening is done in 5-minute periods. Specific sensors are used for different purposes such as; 14 Pt1000 immersion temperature sensors for water temperatures (measuring range: $-30{ }^{\circ} \mathrm{C}$ to $+130{ }^{\circ} \mathrm{C}$, accuracy: $\pm 0.6 \mathrm{~K}$ ), 6 Pt1000 surface temperature sensors for the working fluid (R410A) temperatures (measuring range: $-30{ }^{\circ} \mathrm{C}$ to $+130{ }^{\circ} \mathrm{C}$, accuracy: $\pm 0.8 \mathrm{~K}$ ), a Pt1000 sensor for the outdoor temperature and humidity (measuring range: $-40{ }^{\circ} \mathrm{C}$ to $+70{ }^{\circ} \mathrm{C}$ and 0 to $100 \% \mathrm{RH}$, accuracy: $\pm 0.8 \mathrm{~K}$ and $\pm 2 \% \mathrm{RH}$ ), 4 room-type temperature sensors for indoor temperature (sensing element: LG-Ni 1000, measuring range: $0{ }^{\circ} \mathrm{C}$ to $+50{ }^{\circ} \mathrm{C}$, accuracy: $\pm 0.6 \mathrm{~K}$ ), 2 piezo resistive pressure gauges (pressure ranges: 0 to 60 bars, linearity: $\pm 0.25 \% \mathrm{~F}$.S., total error band: max. $\pm 1.5 \% \mathrm{~F} . \mathrm{S}$, stability: max. $\pm 0.5 \%$ F.S.) for the condenser and evaporator pressures and 2 impeller flowmeters for the flow rates (measurement range: $0.5 \mathrm{l} / \mathrm{min}$ to $1200 \mathrm{l} / \mathrm{min}$, flow velocity: 0.3 $\mathrm{m} / \mathrm{s}$ to $10 \mathrm{~m} / \mathrm{s}$, linearity: $\pm 0.5 \%$ F.S.- at $10 \mathrm{~m} / \mathrm{s}$, repeatability: $\pm 0.4 \%$ of reading, accuracy: $\leq$ $\pm 0.5 \%$ F.S. $+2.5 \%$ of reading). The total uncertainties of the measurements are calculated as $\pm 2.63 \%$ for the water flow rates, $\pm 1.60 \%$ for the pressures, $\pm 2.0 \%$ for the relative humidity of the outlet air, $\pm 4.57 \%$ for the outlet air temperature, $\pm 2.4 \%$ for the indoor air temperature, $\pm 1.6 \%$ for the refrigerant $\mathrm{R} 410 \mathrm{~A}$ temperatures and $\pm 1.2 \%$ for the water temperatures.

Steady-state, steady-flow processes are assumed and mass and energy balance equations are used for calculations;

Compressor (HPI):

$$
\begin{aligned}
& \dot{m}_{1}=\dot{m}_{2, s}=\dot{m}_{2}=\dot{m}_{r e f} \\
& \dot{W}_{c o m p}=\dot{m}_{r e f}\left(h_{2}-h_{1}\right)
\end{aligned}
$$

Condenser (HP2):

$$
\begin{aligned}
& \dot{m}_{3}=\dot{m}_{4}=\dot{m}_{r e f} \\
& \dot{m}_{6}=\dot{m}_{7}=\dot{m}_{\text {cond }} \\
& \dot{Q}_{\text {cond }}=\dot{m}_{\text {cond }} c_{p}\left(T_{7}-T_{6}\right)=\dot{m}_{r e f}\left(h_{3}-h_{4}\right)
\end{aligned}
$$

Evaporator (HP4):

$$
\begin{aligned}
& \dot{m}_{1}=\dot{m}_{5}=\dot{m}_{r e f} \\
& \dot{m}_{8}=\dot{m}_{9}=\dot{m}_{\text {evap }} \\
& \dot{Q}_{\text {evap }}=\dot{m}_{\text {evap }} c_{p}\left(T_{9}-T_{8}\right)=\dot{m}_{\text {ref }}\left(h_{1}-h_{5}\right)
\end{aligned}
$$

Cooling, hot water supply (heating) and combined performance coefficients were determined as follows (Fatouh ve Elgendy 2011);

$$
C O P_{\text {cooling }}=\frac{\dot{Q}_{\text {evap }}}{\dot{W}_{\text {elec }}}
$$




$$
\begin{aligned}
& C O P_{\text {heating }}=\frac{\dot{Q}_{\text {cond }}}{\dot{W}_{\text {elec }}} \\
& C O P_{\text {combined }}=C O P_{\text {heating }}+C O P_{\text {cooling }}
\end{aligned}
$$

\section{Result and discussion}

The data from measurements on an average seasonal day when the weather is clear are evaluated in this section. The variation in the outdoor temperature, outdoor relative humidity and indoor room temperature are continuously measured and followed. The average outdoor temperature throughout the heat pump operation period was $32.9{ }^{\circ} \mathrm{C}$, while the indoor average temperature was $26.1{ }^{\circ} \mathrm{C}$. During the 5-hour cooling period, the indoor temperature is decreased from $30{ }^{\circ} \mathrm{C}$ to $25.6{ }^{\circ} \mathrm{C}$. During the day, outdoor relative humidity varied between $59.4 \%$ and $72.4 \%$ (mean value: $63.5 \%$ ).

The change in condenser and evaporator pressures of the heat pump is also measured. While the condenser pressure was 21 bars during the first operation hours -when the water tank temperature was low-, it raised to 32.3 bar at the end of the operation because of the rise in water tank temperature. Evaporator pressure is measured as 6.3 and 6.5 bar. The average condenser pressure was found to be 26.9 bar while the average evaporator pressure was 6.4 bar.

The refrigerant R410A temperatures are determined at both entrances and exits of compressor, condenser and evaporator. The refrigerant temperature at the exit of compressor ranged between $115.5^{\circ} \mathrm{C}$ to $88.1{ }^{\circ} \mathrm{C}$ (average value: $104.2^{\circ} \mathrm{C}$ ), and the temperature at the entrance of compressor ranged between $17.7^{\circ} \mathrm{C}$ to $12.9^{\circ} \mathrm{C}$ (mean value: $14.6^{\circ} \mathrm{C}$ ). Since the refrigerant firstly passes through the reserve condenser after exiting the compressor, a little amount of heat loss occurs, which leads to a decrease in refrigerant temperature. The temperatures at the entrance of the condenser ranged between $105.5{ }^{\circ} \mathrm{C}$ and $74.4{ }^{\circ} \mathrm{C}$ (mean value: $88.4^{\circ} \mathrm{C}$ ) while the refrigerant temperature exiting in compressed liquid phase from the condenser varied from $48.5{ }^{\circ} \mathrm{C}$ to $30.6{ }^{\circ} \mathrm{C}$ (mean value: $40.3{ }^{\circ} \mathrm{C}$ ). The temperature of the refrigerant in the wet vapor phase at the entrance of the evaporator was $-6.1^{\circ} \mathrm{C}$.

The circulating water between fan coil and heat pump evaporator was also recorded by measuring its outlet and inlet temperatures to the fan coil unit. The minimum temperature of the water used in fan coil unit for cooling was $10.1{ }^{\circ} \mathrm{C}$. Although the temperature both at the entrance and exit of the evaporator is increased in time because of the rise in tank temperature, the average temperature difference is remained as about $3.1{ }^{\circ} \mathrm{C}$. While the temperature of the cooling water at the entrance of fan coil was $12.3{ }^{\circ} \mathrm{C}$, its average return temperature from fan coil was $15.4{ }^{\circ} \mathrm{C}$. Similarly, the variation in the temperatures at the entrance and exit of condenser varied between $25.2{ }^{\circ} \mathrm{C}$ and $48.4{ }^{\circ} \mathrm{C}$ (mean value: $37.5^{\circ} \mathrm{C}$ ) and $30.7{ }^{\circ} \mathrm{C}$ and $52.2{ }^{\circ} \mathrm{C}$ (mean value: $37.5^{\circ} \mathrm{C}$ ), respectively. At the end of the day the maximum water tank temperature was $50.5^{\circ} \mathrm{C}$.

The average flow rate of the water between the tank and heat pump is measured as $2.20 \mathrm{~m}^{3} / \mathrm{h}$, and the flow rate of water between the heat pump and fan coil units is measured as $2.68 \mathrm{~m}^{3} / \mathrm{h}$. Following the thermodynamic calculations, the heat drawn in the evaporator, the heat rejected from condenser, the compressor power and the electric power consumed in the compressor 
are presented in Figure 2. As it can be seen from the figure, the cooling capacity of the device ranges between $12.74 \mathrm{~kW}$ and $6.84 \mathrm{~kW}$. The average power drawn from the condenser drops over time due to the increase of the water tank temperature. As it can be seen from the figure, the condenser power ranges between $14.78 \mathrm{~kW}$ and $9.69 \mathrm{~kW}$. The energy transferred to the refrigerant in the compressor varies between $3.88 \mathrm{~kW}$ and $3.09 \mathrm{~kW}$. During the compressor operation, the current is changed between 6.8 and 7.9 Ampere while the voltage varied between $370 \mathrm{~V}$ and $390 \mathrm{~V}$. Calculations based on corresponding values show that the electrical efficiency of the compressor is $76 \%$ on average. The electric power consumed by the compressor considering its efficiency varies between $5.10 \mathrm{~kW}$ and $4.07 \mathrm{~kW}$.

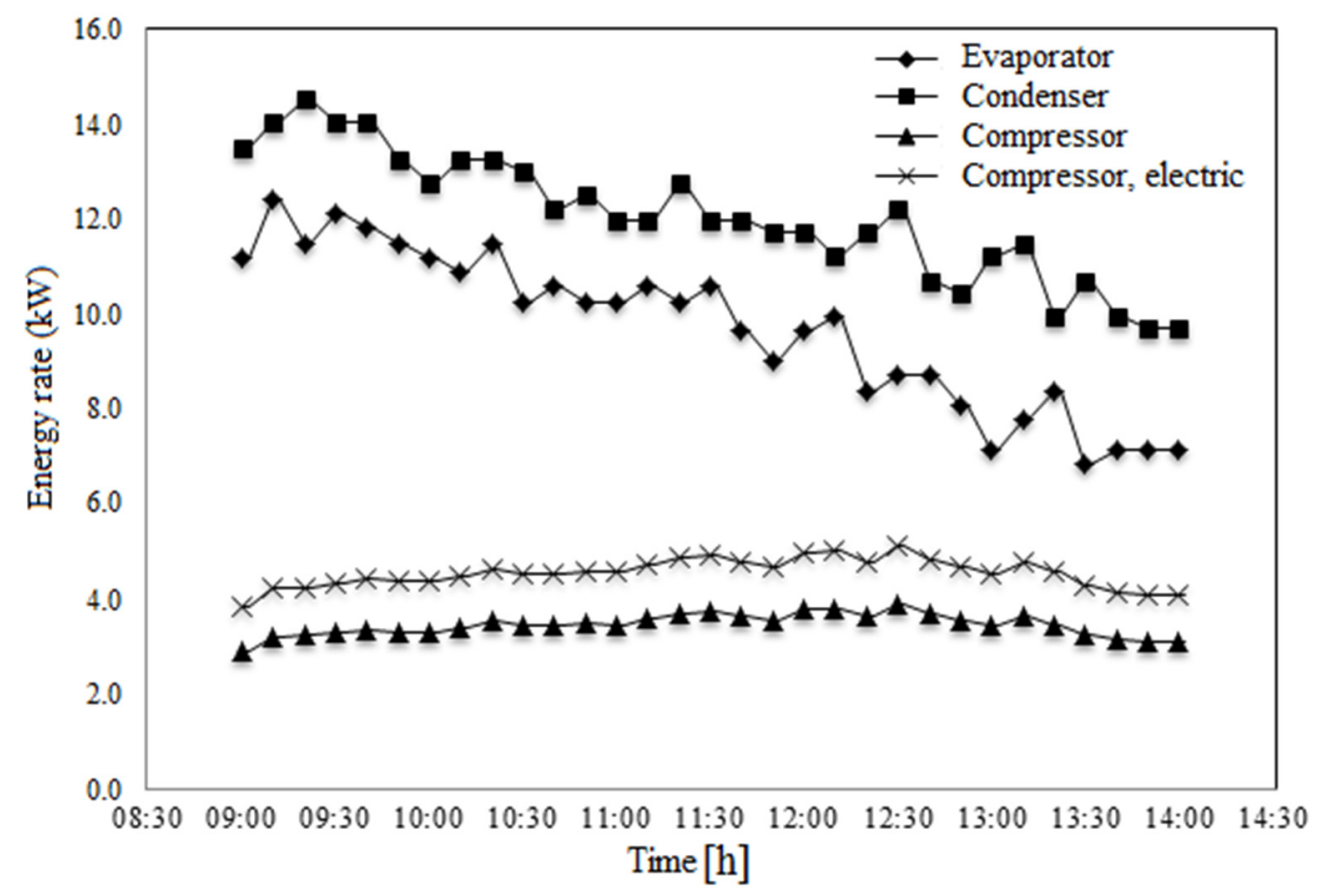

Figure 2. Energy analysis results of the system.

The variation of heating and cooling COP of the heat pump under previously mentioned operating conditions is given in Figure 3. It is clear from the figure that the cooling COP was partially higher in the first hours when the water tank temperature was low, but started to decrease slightly in the following hours. During the operation hours, the lowest cooling COP was 1.57 and the highest cooling COP was 2.82 (mean cooling COP value: 2.08 ). On the other hand, the lowest and highest values for heating COP were 2.16 and 3.35, respectively (mean cooling COP value: 2.61). The maximum combined COP value which is calculated for simultaneous cooling and hot water supply, was determined at the start of operation and is 6.10. In addition, minimum combined COP was 3.94 and the average combined COP was 4.69. 


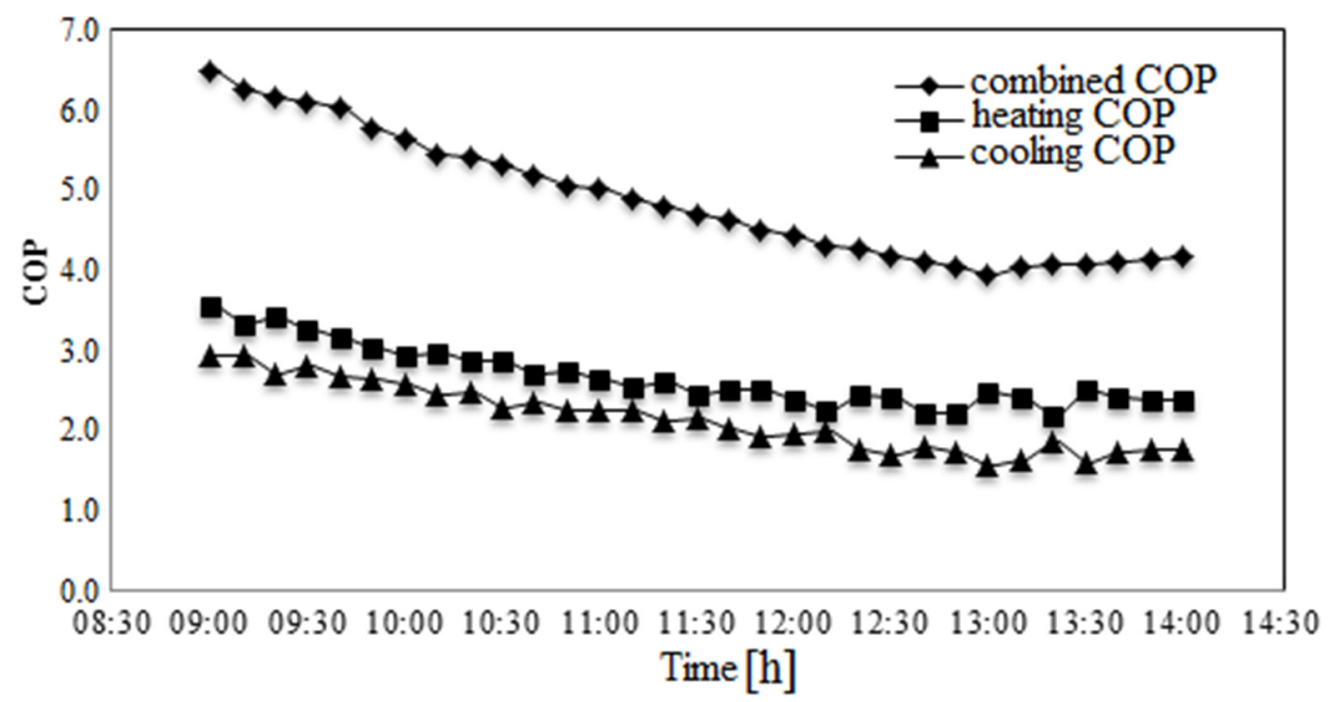

Figure 3. Variation of the COP during the day in the heat pump operation hours

\section{Conclusion}

In this study, a water-to-water heat pump installed under controlled conditions is investigated. The system is operated under summer conditions to make simultaneous cooling and hot water supply. The cooled space was $110 \mathrm{~m}^{2}$ laboratory and the rejected heat is transferred to 2-ton capacity tank where the hot water is obtained. The instantaneous behavior of the system for a sample day is addressed. The results show that the cooling and water heating COP values are partially higher when the water temperature is low and it decreases to some extent as the water tank temperature increases. For an instantaneous analysis in the sample day, the mean cooling COP value was found to be 2.08 and the water heating COP value was found to be 2.61. Because of the preferred experimental method, the water tank temperature is constantly increased due to unused water during the operation hours. If the hot water supply would have been used, the system had higher COP because of continuous city water addition.

\section{References}

[1] Jiang, H., Jiang, Y., Wang Y., Ma, Z. and Yao, Y. "An experimental study on a modified air conditioner with a domestic hot water supply (ACDHWS)." Energy, 31 (2006): 1789 - 1803.

[2] Shao, S., Shi, W., Li, X. and Ma, J. "A new inverter heat pump operated all year round with domestic hot water." Energy Conversion and Management, 45 (2004): 2255-2268.

[3] Fatouh, M. and Elgendy, E. "Experimental investigation of a vapor compression heat pump used for cooling." Energy, 36 (5) (2011): 2788-2795.

[4] Hamamatsu, T., Iwatsubo, T. and Saikawa, M. "Development of advanced heat pumps for room cooling, heating and hot water supplying." Heat Pumps Solving Energy and Environmental Challenges, (1990) 477-486.

[5] Kuang, Y.H. and Wang, R.Z. "Performance of a multi - functional direct expansion solar assisted heat pump system." Solar Energy, 80 (2006): 795-803.

[6] Inalli, M. and Esen, H. "Seasonal cooling performance of a ground-coupled heat pump 
system in a hot and arid climate." Renewable Energy, 30 (2005): 1411 - 1424.

[7] Hepbasli, A. and Akdemir, O. "Energy and exergy analysis of a ground source (geothermal) heat pump system." Energy Conversion and Management, 45 (2004): 737753. 